Copyright (C) 2015 by Academic Publishing House Researcher

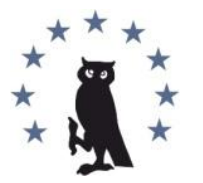

Published in the Russian Federation

European Researcher

Has been issued since 2010.

ISSN 2219-8229

E-ISSN 2224-0136

Vol. 98, Is. 9, pp. 658-666, 2015

DOI: $10.13187 /$ er.2015.99.658

www.erjournal.ru

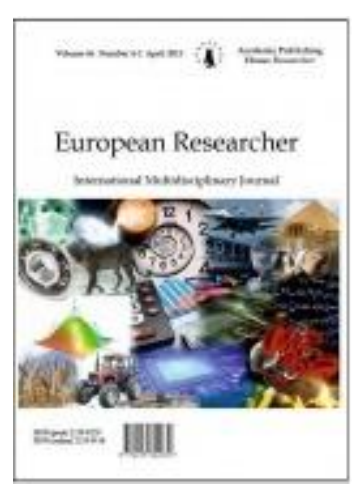

Economic sciences

Экономические науки

UDC 33

\title{
Impact of Mobile Remittances on the Performance of Banks in Pakistan: A Panel Data Analysis
}

\author{
${ }^{1}$ Raheel Ahmed \\ ${ }^{2}$ Khurrum S. Mughal \\ 3 Aneel Salman \\ ${ }_{4}^{4}$ Nedim Makarević
}

${ }^{1}$ Iqra University, Islamabad

E-mail: ahmed.raheel14@gmail.com

${ }^{2}$ COMSATS Institute of Information Technology, Islamabad

Dr.

E-mail: khurrum.mughal@gmail.com

3 COMSATS Institute of Information Technology, Islamabad

Dr.

E-mail: aneel.salman@comsats.edu.pk

4 Embassy of Bosnia and Herzegovina in Pakistan

Dr.

E-mail: nmakarevic.science@gmail.com

\begin{abstract}
The research aimed to explore the effect of a new technological development, Mobile Remittance, on the profitability of Pakistani banks. For this purpose five bank's data have been chosen over the period of 5 years, i.e., from 2009-2013. Return on Assets is used as the proxy for measuring bank profitability. The empirical result of this study show that mobile remittances, offbalance sheet activities and capital adequacy ratio have a positive coefficient which indicates that these variables play an important role to increase banks profitability. The credit risk has a negative coefficient that shows that increase in the ratio of credit risk decreases the bank's performance.

Keywords: banks performance, branchless banking, mobile remittances, capital adequacy, credit risk.

\section{Introduction}

According to Pakistan Telecommunication Authority (PTA), in Pakistan total $136,630,891$ people are using mobile connections (PTA, Feb 2005). For identifying the gap and to exploit the potential market, financial institutions have developed different schemes to bring these people in
\end{abstract}


banking channels, with the collaboration of telecommunication companies under different names such as Time-Pay, Easy-Paisa, mobi cash, UBL Omni, Upaisa.

Mobile banking is an emerging user-friendly service by the banking industry. Such a fusion took place in early 2001 between telecommunication industry and the banking industry, with the introduction of mobile banking via SMA and browser (Vats and Mohan, 2008). Mobile banking is the further extension of branchless banking. The introduction of mobile banking makes it convenient for people to control operations of their personal accounts, make payments for utilities, transfer funds anywhere, know about banking products through mobile anytime and from anywhere (Mas, 2009).

The telecommunication sector plays a significant role in the development of mobile banking, Collaboration between banking and telecommunication industry will have a direct impact on their sale volume, profitability and customer base (Kiganane et al, 2012). Some researchers and policy makers are of the view that the system will channelize the transactions previously made out of the banking channel and help in documenting the economy.

Keeping in view the competitive advantage, branchless banking was introduced in recent years by implementing the technological advancements in the banking sector. The core of these initiatives was to provide customers a convenient banking service without having to visit the bank (Tobin, 2012). Technological advancements in the telecom sector and strategic collaboration with the banking sector opened a new horizon for the researchers to analyze the impact of mobile banking on telecom and banking sectors from different aspects.

The financial health is very critical for banks and telecom operators, which are involved in this mobile remittance services. The impact of mobile remittances on the financial performance of the banks and how much additional revenue these institutes are generating through earning from mobile banking transactions or remittances was studied in this research.

This study helps to find out whether mobile remittances effects the performance of those banks, i.e Tameer microfinance bank, United bank of Pakistan, Askari bank of Pakistan, Waseela Microfinance bank and U microfinance bank which are involved in the mobile banking in Pakistan. The primary reason of this investigation in banking sector is that it is the backbone of Pakistan's economy; since the growth in this sector have a direct impact on the growth of the economy. Moreover, the usage of mobile banking is increasing day by day in Pakistan, and this study provides a direction for those banks/telecom operators who have not yet adopted the services of mobile remittances.

\section{Literature Review}

The trend of banking is now shifting from the basic brick \& mortar banking towards branchless banking. Most of the banks now offer the service through their different point of sales, retail agents or partnership with other sources. Facilities of ATMs, Credit Cards and Debit Cards provided by the banks to customers, increase convenience for the customers (Sana et al., 2011). Okiro \& Ndungu (2013) had defined the mobile banking as

"Mobile banking (M-banking) refers to provision and an ailment of banking and financial services through the help of mobile telecommunication devices"

The aim of these services was to take the banking transaction system out of the basic branches with the help of agents; it may be grocery stores, tuck shop or similar type of business (Mas, 2009). This mode of financial inclusion made banking system faster and reliable, now the customer get service at any time more quickly (Njenga, 2011). With this innovation the local and international transactions were becoming faster and take less time as taken before for these transactions. It gives services to the customer through 24/7 (24 hours \& 7 days a week) at any place through their retail agents (Caruso, 2013).

The mobile remittance first started in the Kenya in 2004 with the name of M-Pesa. The basic aim of this service was to provide convenience to bottom of pyramids consumers (BOP) who did not have a bank account or were hesitant of the banking services. Banks now partnered with telecom sector provide financial services where they did not want to open the bank branches or branches were more costly, hence they offered mobile banking services to these areas to capture the unbanked customers. They provided services like bill payment, loans provision, cash withdrawals 
or deposits which were very helpful for BOP consumers to attain the benefit of these services easily (Reeves \& Neha, 2013).

There were many mobile banking services operating in different countries with different names \& logos. The first service started with the name of M-Pesa with the collaboration of Safricom and Vodacom in 2004 in Kenya. After Kenya, South Africa had also started their branchless or mobile banking service for unbanked customers in 2004 with a name of WIZZIT. In Philippine they launch G-Cash for the unbanked customers in the same year.

In Pakistan the era of mobile banking started in 2008 when Telenor, a telecom operator, joined hands with Tameer Microfinance bank for the provision of services. After this the State Bank of Pakistan (SBP) issued the policy paper regarding branchless banking rules and regulations in Pakistan, 2008. Some guidelines printed by SBP that were necessarily followed for the starting up mobile banking in Pakistan. Following were the some guidelines:

Only bank-led model was applicable, Branchless banking can be started with the collaboration / understanding with the bank and telecom service providers. In the (SBP, Branchless Banking Guidelines, 2008) divided Branchless banking into three proposed models: which were as follows;

A. One to One Model (1-1)

In this model, only one bank can be collaborated with only one telecom service providers (those who were registered with PTA).

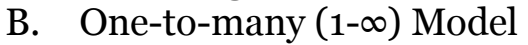

In this model, the only one bank can be collaborating with many telecom service providers. Through this model, there will be an opportunity to access to any other customer who had different mobile phone connection.

C. Many-to-many $(\infty-\infty)$ Model

In this model, many banks can be collaborated with many telecom service providers, to join hands for the provision of the financial services to the any mobile phone connection customer.

The mobile banking operators (agents) can provide services, i.e. Remittances, Loan Disbursement/Repayment, Bill payments, Cash-in and Cash-out, Person-to-Person Fund Transfers, Account-to-Account Fund Transfer, Opening and maintaining of the BB account (SBP Guidelines, 2008).

State bank of Pakistan in his policy paper concluded that branchless banking was a cheaper alternative then the brick and mortar branch banking. That helps financial institutions to offer financial services without the basic banking network through different sources like retail agents, mobile phone etc. this could help the banks to reach those customers who were in the remote areas of the country and unbanked (SBP, Report on Branchless Banking, 2008).

Following mobile banking services were working in Pakistan:

\section{Easy Paisa}

In October, 2009 the Telenor (Telecom Company) joint hands with Tameer bank one of the microfinance banks operated their services in Pakistan, for the first branchless banking service through telecom sector which referred as mobile banking in some of the research papers. Telenor had $51 \%$ of the shares, while the remaining shares had a Tameer Microfinance Bank. The name given to this service was Easy Paisa. The service providers were paying different types of bills, sending/receiving money within the country; load for their cell phones and for the use of denotations.

\section{UBL Omni}

In April, 2010 the United Bank of Pakistan launches its branchless banking in the name " $U B L$ Omni Dukaan" becomes the $2^{\text {nd }}$ largest branchless network in Pakistan. Omni Dukaans were in almost more than 650 cities in Pakistan, included towns and villages that help in accessing the poor people who had not a traditional bank account. The people who had a UBL Omni account were using their lot of services like cash withdraw or deposit, make utility bills, postpaid mobile payment, pay zakat or other donations through SMS, Mobile Applications, their Net banking and ATM through their nearly located shops, without waiting the bank branches (UBL Omni, Web). 


\section{Mobi Cash}

In November, 2012 Mobi Cash was introduced by the Mobilink, one of the top company of telecom service provider, and in his honor as the first cellular company of the Pakistan as telecom operator. They introduced their branchless banking services in the name of Mobi Cash with the partnership of Waseela Microfinance Bank a microfinance institution operating in the country.Like the others branchless or mobile banking operated in Pakistan, the Mobi Cash was providing services like that paying different types of bills cash in or cash out services and providing airtime to their customers. Mobi Cash offers "Mobi cash Beema" to their customer one of the unique life insurance service to their customers who had an account (Mobi Cash, Web).

Time Pay

The Askari Bank and China Mobile Company Zong introduce the branchless or mobile banking in the Pakistan in the name of "Timepey" in November, 2012. Through this service the Askari bank extends their network by providing services like bill payments, sending or receiving money, etc. with the help of this new technology. This can help with those customers who don't have a bank account or to remote areas of the people. From this technology, it was helpful for the employees to get salary at the exact date. The account holder of the time pay receives their salary through this account and also used for the Army salary disbursement purposes. (Time pey, Web).

\section{U-Paisa}

In August, 2013 the U-fone a telecom company introduced "U-Paisa" with the collaboration of $U$ bank formally Rozgar microfinance bank. This service also used for sending and receiving of the money, bill payments, etc. for the people who were in the remote areas of the country or had no bank account. (UPaisa, Web). U Bank and EFU life insurance Company provided insurance facilities to their customers in collaboration. U Microfinance banks also provided facility to Sui Northern Gas Company employees for the online payments to their customers. There are so many operators now working in Pakistan like UBL Omni, Upaisa, TimePay etc.

Based on extensive utilization of Mobile remittances and involvement of multiple banks and telecom operators, we expect a positive significant impact on Bank's performance.

\section{Methodology}

The focus of this study is to determine the impact of mobile remittances on the performance of banks involved in mobile banking in Pakistan while using credit risk, off balance sheet activities and Capital Adequacy as control variables. For this purpose, return on assets (ROA) is taken as the measure of a bank's performance. ROA is one of the variables which are used for the measurement of a firm's performance (Akrofi, 2012).

The research model as derived from the literature review is as under:

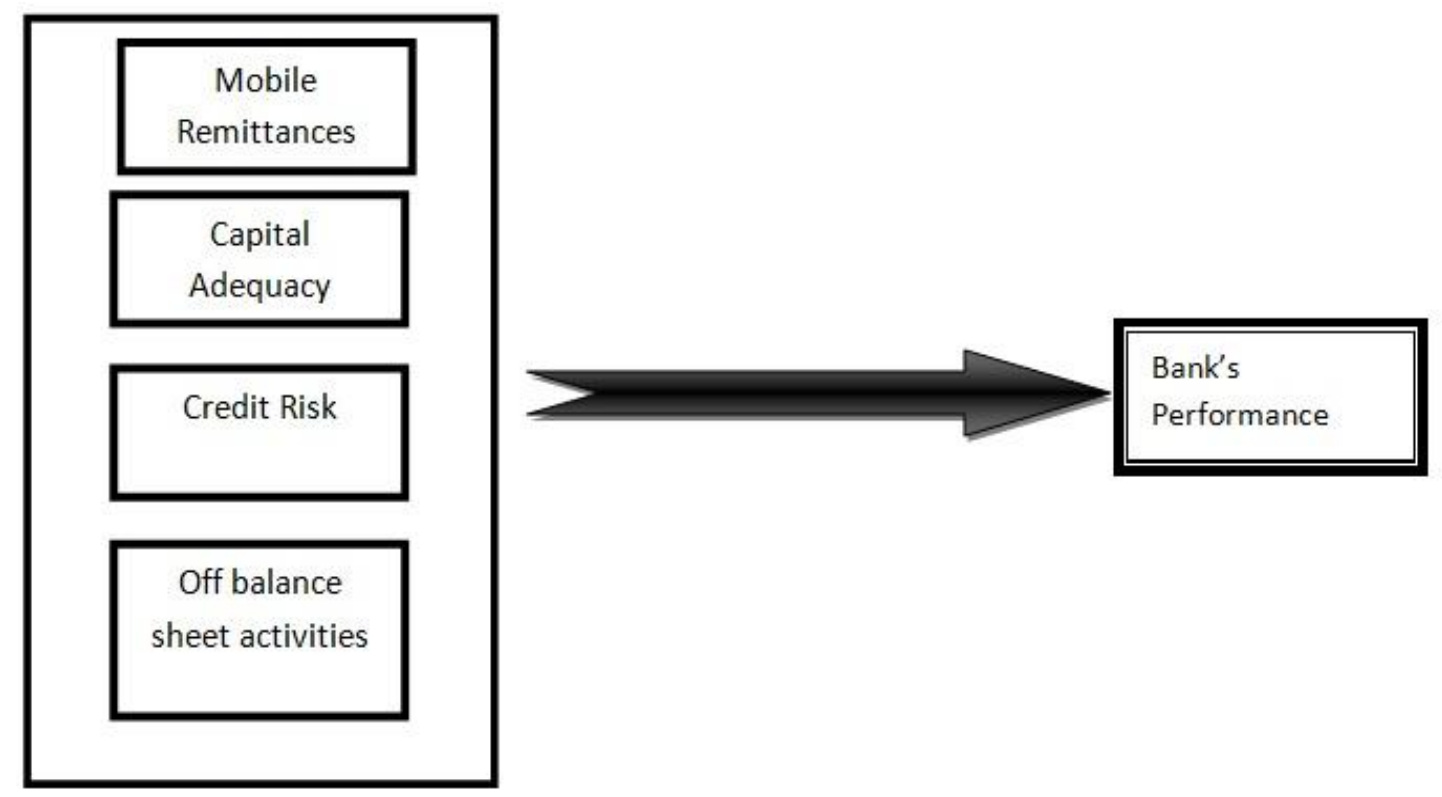


In order to conduct an analysis, it is necessary that measurements of each variable are defined along with the source of collected data.

Bank Profitability

Bank profitability is used as dependent variable in this study. Return on assets is used to measure the profitability of the bank. The data for the bank profitability taken from annual reports of respective banks used in the study. The formula used by (oney at all, 2012) to measure ROA is

Mobile Remittances

$$
R O A=[\text { Net Income } / \text { Total Assets }] \times 100
$$

Mobile remittances are a transfer of money from national workers to an individual within the country. In this study it is used in the percentage change form. The Mobile remittances data taken from the state bank of Pakistan annual reports regarding branchless banking.

Credit Risk

Elsiefy (2013) said that credit risk arises when a borrower fails to meet the requirements of the contract. In banks it arises from the lending activities and some other sources such as counter party default or from some debt based securities. The data for the credit risk taken from annual reports of banks used in the study. The formula used by (Omer \& Mutairi, 2012) to measure the Credit Risk is

$$
\text { Credit Risk }=[\text { Loan } / \text { Total Assets }] \times 100
$$

Capital Adequacy

Capital adequacy ratio is the ratio that is used to show internal strength of the bank in the crises period (Ongore and Kusa, 2013).The data for the capital adequacy is taken from annual reports of banks. (Ongore \& Kusa, 2012) used ratio to measure the capital ratio that is

Capital Ratio $=[$ Total Capital $/$ Total Assets $] \times 100$

Off Balance Sheet Activities

The Off balance sheet activities of the banks are those activities which are non interest based and are not on regular basis. The data for the Off balance sheet activities is taken from annual reports of banks used in the study The measurement used for estimating off balance sheet activities by (Casu and Girardone, 2012) is

Off balance sheet activities $=[$ Non Interest Income $/$ Total Assets $] \times 100$

The data for this study was gathered from annual financial reports of United Bank of Pakistan Ltd, Askari bank Ltd, Tameer Microfinance bank Ltd, U Microfinance Bank Ltd and Waseela Microfinance Ltd. All these banks perform the services of mobile or branchless banking in Pakistan. The State bank of Pakistan is also used as a secondary source for collection of data for branchless banking. Various banks involved in branchless banking were personally surveyed for data collection purpose. The study considered only five banks (i.e. Askari bank, United Bank, Tameer Microfinance Bank, Waseela Microfinance Bank, Rozgar Micro Finance Bank) because only these five banks are involved in mobile banking. The sample for this study constituted panel data of above-mentioned banks for last 5 years i.e. 2009-2013 because mobile banking was started in 2009.

\section{Results and Discussion}

Summary statistics were used to find out the mean, standard deviation, maximum and minimum value of each and every variable in our dataset. The skeweness and kurtious test of normality were used to check the normality of data. In this study the ADF Augmented Ducky Fuller test was used to test whether our panel contains unit root or not. To check the linear relationship between two continuous variables, correlation method was used. Fixed and Random Effects regressions were used to find the effect of independent variables on the dependent variable. After the regression analysis then Hausman test was used to identify either fixed or random effect model will use in estimation.

Summary Statistics of the collected data are placed in Table 1 below. 
Table 1: Summary Statistic

\begin{tabular}{|l|c|c|c|}
\hline \multicolumn{1}{|c|}{ Variables } & Observations & Mean & Standard Deviation \\
\hline ROA & 20 & 2.683333 & 2.630876 \\
\hline MR & 20 & 7.64175 & 13.8251 \\
\hline CR & 20 & 5.380479 & 5.402373 \\
\hline Cap Adq & 20 & 31.00052 & 34.46067 \\
\hline OBS & 20 & 2.548072 & 2.605694 \\
\hline
\end{tabular}

In the above table the mean value for the dependent variable Return on Assets is 2.683333 and its standard deviation is 2.630876. While in main variable of interest that is mobile remittances have the mean value is 7.64175, its Standard Deviation is 13.8251 .

After summary statistics normality test used to identify that either the data used in study is normal or not. The normality table 2 shown below that all the variables used in this study have a pvalue of less than 0.05 which means the variables are normal.

Table 2: Normality Test

\begin{tabular}{|l|c|c|c|}
\hline Variable Name & Pr(skewness) & $\operatorname{Pr}$ (Kurtious) & P-value \\
\hline Return on Assets & 0.000 & 0.002 & 0.000 \\
\hline Mobile Remittances & 0.000 & 0.0004 & 0.000 \\
\hline Credit Risk & 0.000 & 0.001 & 0.000 \\
\hline Capital Adequacy Ratio & 0.049 & 0.041 & 0.009 \\
\hline Off balance sheet activities & 0.0084 & 0.01137 & 0.0081 \\
\hline
\end{tabular}

Correlation matrix is used to check the relationship between the dependent and independent variables. The correlation table 3 indicates the correlation between dependent, independent and other control variables.

Table 3: Correlation Matrix

\begin{tabular}{|l|l|l|l|l|l|}
\hline Variable Name & ROA & MR & OBS & CR & Cap Adq \\
\hline ROA & 1 & - & - & - & - \\
MR & & & & - & - \\
\hline OBS & 0.0225 & 1 & - & - & - \\
\hline CR & 0.7013 & 0.4744 & 1 & - & - \\
\hline Cap Adq & -0.3166 & 0.2311 & 0.2321 & 1 & 1 \\
\hline
\end{tabular}

In this correlation matrix, some variables have a negative relationship with the main independent variable Mobile Remittances like Capital adequacy ratio. While In Correlation matrix table Return of Assets has a negative correlation with the Credit Risk. While Return on Assets have a positive correlation with the independent variable and other control variable in the study. 
Regression results:

The methodology included use of OLS, Random Effects and Fixed Effects for the analysis of Data. The results of Hausman Test showed preference for Random Effects hence depicting that there is no unobserved heterogeneity in the data. The results of OLS and Random Effects are displayed in the table 4 below:

Table 4: Regression Model Results

\begin{tabular}{|c|c|c|c|}
\hline \multicolumn{3}{|c|}{ Dependent Variable: Return on Assets (ROA) } & $\mathrm{n}=20$ \\
\hline \multicolumn{2}{|l|}{ Variable } & OLS & Random Effects \\
\hline Mobile Remittances & MR & $\begin{array}{c}0.0587966 \\
(3.47)\end{array}$ & $\begin{array}{c}0.0587966 \\
(3.26)\end{array}$ \\
\hline Credit Risk & $\mathrm{CR}$ & $\begin{array}{c}-0.1369031 \\
(-4.12)\end{array}$ & $\begin{array}{c}-0.1369031 \\
(-5.6)\end{array}$ \\
\hline Capital Adequacy & Cap Adq & $\begin{array}{c}0.0233465 \\
(2.46)\end{array}$ & $\begin{array}{c}0.0233465 \\
(2.99)\end{array}$ \\
\hline Off balance sheet activities & OBS & $\begin{array}{c}0.09283223 \\
(13.09)\end{array}$ & $\begin{array}{c}0.9283223 \\
(9.95)\end{array}$ \\
\hline \multicolumn{2}{|l|}{ Constant } & 0.7800604 & 0.7800604 \\
\hline & $\mathrm{R}-\mathrm{S}$ & 0.9065 & 0.9065 \\
\hline
\end{tabular}

In above table the $\mathrm{t}$-values are given in parenthesis under each variable. The table shows $\mathrm{R}^{2}$ has a value of $90.65 \%$ which describe that the proportion of the variation in the dependent variable which is explained by the variation in the independent variables. While the adjusted $\mathrm{R}^{2}$ describes the overall goodness level of the model, and also have an explanatory power. Based on the results of the multiple linear regression effect of each variable is discussed below.

In above table Mobile remittances show a significant positive impact on the bank performance. Because it can generates new source of income for the bank's profitability. So it has a positive relationship with the dependent variable. The coefficient of mobile remittances is .0587966. It means that 1 percent increase in the mobile remittances causes slightly more than half a percentage increase in Return on Assets. It means that if the ratio of mobile remittances increases the banks have a chance to increase their profit ratio. This effect is statistically as well economically significant. Along with this all the control variables appeared with expected signs and are statistically significant. Capital adequacy ratio has a significant and a positive relationship with the dependent variable return on assets. Its coefficient value is .0233465 means that an increase in 1\% increase in capital adequacy ratio affects 0.0233 percentage increase in the return on assets, which is a significant and positive relationship with the dependent variable. As in the previous literature this study shows that credit risk has a significant negative effect on bank's performance. The coefficient of Credit Risk is -0.1369031, which means that 1\% increase in Credit Risk affects 0.1369 percentage decrease in Return on Assets.

Both the models show that off balance sheet activities have a significant and a positive impact on the performance of banks. Its coefficient value is .09283223 mean that as off balance sheet activities increase by $1 \%$ the return on assets increases by 0.0928 percent.

\section{Conclusion and Recommendation}

This research observes the factors affecting the profitability of Pakistani banks. For this study those banks were taken which are involved in the branchless banking service in Pakistan. These banks are United bank Ltd, Askari bank Ltd, Tameer Microfinance bank, Waseela microfinance bank and U microfinance bank Ltd.

In this study independent variable mobile remittance shows a significant and positive impact on bank's performance. It shows that the inclusion of new ways of a business by the banks provided them a platform for generating a new stream of revenues. It showed that with the inclusion of 
branchless banking services in banks; their profitability can be increased. It reduces the operational cost of the bank which might be incurred by opening new branches in backward areas of the country. Now banks only provide branchless banking services where it is economical. People are more convenient by using this service because it eliminates the wastage of time while waiting in long queues within banks. Various different services that are provided by the banks to their customers are paying different types of bills; send/receive money within the country, pays charges for their cell phones and for the use of donations. The customers can avail these services 24/7 throughout Pakistan using just their National Identity Card.

On the basis of the results of this study following are some recommendations for the banks;

1. Banks should focus more on those undeveloped areas of the country where there are no operational branches of banks. As revealed from the results, branchless banking increases the profitability of the banks.

2. Credit risk is one of the hindrances in the progress of the banks because it decreases the bank profitability. So banks should focus to minimize this risk through proper investigation of the borrowers. Through decrease in the credit risk, banks can also increase the capitalization. This capitalization will be helpful for the banks to invest more in risky projects where other low capital banks fear to invest.

3. The Government of Pakistan and companies involved in this ever growing field should make legislation in order to expand these services within the country and later outside the country.

\section{References:}

1. Anum, J.B., \& Rana,A.Q. (2012). Internal and External Determinants of Profitability of Banks: Evidence from Pakistan. Interdisciplinary Journal of Contemporary Research businesses, Vol. 3(9). 1037-1058.

2. Bahram, M., Zeinab, V., and Hussein, M.(2013). The Effect of Using Electronic Banking on Profitability of Bank. Interdisciplinary journal of contemporary research in business, Vol.4(12). 1299-1318.

3. Carlos, F., Miguel, G., and E, T. (2006). How bricks-and-mortar attributes affect online banking adoption. International Journal of Bank Marketing, Vol. 24(6). 406-423.

4. Charles, O. O., \& Uwem, E. (2005). Managing information and technology: critical roles for librarians in developing countries. The Electronic Library, Vol. 24(6). 847-863.

5. Charles, O. O., Uwem, E. (2006). Roadmap to Change: Emerging Roles for Information Professionals Library Review, Vol. 55(4). 267-277.

6. Fadzlan, S., \& Muzafar, S. H. (2009). Banks specific and macroeconomic determinants of bank profitability, Empirical evidence from the china bank, Vol. 3(4). 274-291.

7. Faisal, K. M., Ahmad, A., Lim, G.C ., \& Hashim, K. (2011). Determinants of Bank Profitability in Pakistan: A Case Study of Pakistani Banking Sector. World Applied Science Journal, Vol. 15(10). 1484-1493.

8. Gabrieline, O., A. (2006). Training Needs and Methods of Training in Information Technology in the Oil Industry Libraries the Electronic Library, Vol. 24(1). 267-275.

9. Gaetan, B., \& Louise, C. (2006) .Profit and the legitimacy of the Canadian banking industry: Accounting, Auditing \& Accountability Journal, Vol. 19(4). 512-539.

10. Permissible Models (2008), Branchless Banking Regulations for Financial Institutions Desirous to undertake Branchless Banking, Department of Banking Policy \& Regulations, State Bank of Pakistan (March 31, 2008), 
УДК 33

\title{
Влияние мобильных денежных переводов на производительность банков в Пакистане: анализ панельных данных
}

\author{
${ }^{1}$ Рахиль Ахмед \\ ${ }^{2}$ Хуррум С. Мугхаль \\ 3 Анель Салман \\ ${ }_{4}^{4}$ Недим Макаревич
}

${ }^{1}$ Университет Икра, Исламабад, Пакистан

E-mail: ahmed.raheel14@gmail.com

${ }^{2}$ КОМСАТС Институт Информационных Технологий, Исламабад, Пакистан

E-mail: khurrum.mughal@gmail.com

3 КОМСАТС Институт Информационных Технологий, Исламабад, Пакистан

E-mail: aneel.salman@comsats.edu.pk

4 Посольство Боснии и Герцеговины в Пакистане, Пакистан

E-mail: nmakarevic.science@gmail.com

Аннотация. Целью исследования было изучить влияние нового технологического развития, мобильных денежных переводов, на рентабельность пакистанских банков. Для этой цели были выбраны данные пяти банков за период 5 лет, то есть, за 2009-2013 гг. Рентабельность активов используется в качестве прокси-сервера для измерения прибыльности банка. Эмпирические результаты этого исследования показывают, что мобильные денежные переводы, забалансовая деятельность и коэффициент достаточности капитала имеют положительный коэффициент, который указывает, что эти переменные играют важную роль в повышении рентабельности банков. Кредитный риск имеет отрицательный коэффициент, который показывает, что увеличение соотношения кредитного риска снижает производительность банка.

Ключевые слова: показатели банка, дистанционный банкинг, мобильные переводы, достаточность капитала, кредитный риск. 